\title{
THE CONSTITUTION'S FORGOTTEN COVER LETTER: AN ESSAY ON THE NEW FEDERALISM AND THE ORIGINAL UNDERSTANDING
}

\author{
Daniel A. Farber*
}

\section{INTRODUCTION}

At the end of the summer of 1787, the Philadelphia Convention issued two documents. One was the Constitution itself. The other document, now almost forgotten even by constitutional historians, was an official letter to Congress, signed by George Washington on behalf of the Convention. ${ }^{1}$ Congress responded with a resolution that the Constitution and "letter accompanying the same" be sent to the state legislatures for submission to conventions in each state. ${ }^{2}$

The Washington letter lacks the detail and depth of some other evidence of original intent. Being a cover letter, it was designed only to introduce the accompanying document rather than to plumb its meaning. But the letter's official nature gives it a status not shared by Madison's personal notes or newspaper editorials such as the Federalist Papers. As we will see, the Washington letter contains significant clues about the nature of the document that the Convention was placing before the country. Although it cannot supplant other, more traditional sources, it can help to illuminate the original understanding of the Framers. ${ }^{3}$

Recourse to this source is particularly appropriate now, in a year when we have twice been admonished to return to the "first

* Acting Associate Vice-President for Academic Affairs, Associate Dean for Faculty Research and Development, and Henry J. Fletcher Professor of Law, University of Minnesota. B.A. 1971, M.A. 1972, J.D. 1975, Illinois. - Ed. I would like to thank Jim Chen, Phil Frickey, Mark Killenbeck, Mike Paulsen, Jeff Powell, and Suzanna Sherry for their helpful comments.

1. See Letter of the President of the Federal Convention to the President of Congress (Sept. 17, 1787), in Formation OF the UNION OF THE AMERICAN STATES 1003 (Charles C. Tansill ed., 1927). A complete copy of the letter can be found in the Appendix to this essay.

2. See Resolution of Congress of September 28, 1787, Submitting the Constitution to the Several States, in FoRMATION OF THE UNION, supra note 1, at 1007.

3. Except where the context makes it important to draw a distinction, this essay uses the term Framers to refer to both the Philadelphia Convention and the ratifiers. 
principles" of federalism. ${ }^{4}$ On one of these occasions, departing from almost sixty years of past practice, the Court ruled that Congress had exceeded its power to regulate private activity under the Commerce Clause. 5 In the other case, only the defection of Justice Kennedy prevented the same block of Justices from holding that ultimate sovereignty lies in the people of the individual states, rather than in a single national populace. 6 "We, the People," according to these Justices, means "we the peoples of the various states," rather than "We the American people."7

It is only fair to consider the extent to which these "first principles" are congruent with the views of those who framed the Constitution. But the multitude of available sources, many of them conflicting, ambiguous, or unreliable, complicates this inquiry. The Convention's cover letter provides useful assistance because of its official standing as the unanimous public expression of the Convention's views. In this respect, it compares quite favorably with Madison's notes, which were not available to the public until many years later, and with the Federalist Papers, which presented the unofficial views of two prominent delegates. ${ }^{8}$ Further, because it seems to have been regarded as noncontroversial, both in the Convention and elsewhere, it may help illuminate the most important of understandings - those that were considered too clear to require discussion.

This essay uses the Washington letter to test current assertions about the original understanding of federalism. Part II of the essay explores the New Federalism - the emerging conservative theory of federalism. Although the New Federalism had its most dramatic impact in Lopez and its most radical expression in the Term Limits dissent, it began in a series of earlier opinions and in the work of conservative constitutional theorists. Part II traces this development. Part III then considers the significance of the Washington letter in more detail. As Part III explains, recent conservative writings about interpretation provide strong reasons to reassess the traditional obscurity of the Washington letter. With these preliminaries out of the way, Part IV uses the Washington letter to

4. See United States Term Limits, Inc. v. Thomton, 115 S. Ct. 1842, 1875 (1995) (Thomas, J., joined by Rehnquist, C.J., O'Connor, J., and Scalia, J., dissenting); United States v. Lopez, 115 S. Ct. 1624, 1626 (1995).

5. See Lopez, 115 S. Ct. at 1653 (Souter, J., dissenting).

6. See Term Limits, 115 S. Ct. at 1875.

7. See 115 S. Ct. at 1876 n.1.

8. With the minor exception of the handful of Federalist Papers authored by John Jay. 
probe three elements of the New Federalism: its understanding of the scope of national power; its concept of sovereignty; and its vision of the states as safeguards against the federal government. Part V contains some brief closing thoughts about the Washington letter and the New Federalism.

In general, the Washington letter supports the arguments of historians who have attributed a more nationalist spirit to the Framers than that contemplated by the New Federalists. ${ }^{9}$ To the extent that their goal is to keep faith with the spirit of the Framers, the New Federalists seem to have struck a somewhat dissonant chord. If the burden of proof is on the New Federalists to justify a change in current law, they have failed to carry that burden. ${ }^{10}$

It is important to bear in mind the limited extent of the current dispute over federalism. The Constitution undeniably contemplates the existence of the states as important elements of the structure of government. The federal government clearly was the recipient of enumerated powers, and any remaining powers of government were reserved to the states. But the question is how to construe that reservation to the states.

We might analogize the reserved powers of the state to the share of a residuary legatee in a will. On the one hand, the Framers may have thought it critically important that the states retain substantial regulatory autonomy. If so, courts have reason to construe the specific bequests so as to maintain a substantial residue. That is the New Federalist view. Or perhaps the states were more like a charity chosen for tax purposes to inherit the residue of the estate - here, that being whatever powers happened to be left over or whatever authority Congress chose not to exercise. Although the Framers may have expected the residuary bequest to be large, maintaining its size may not have been an important goal of their constitutional testament. If so, it should play little role in construing the specific bequests. In approaching this question, it is helpful to understand the overall "estate plan," which in this case is clarified to some degree by the Washington letter, as well as the place of the residuary legatees in the testator's affections.

9. See infra text accompanying notes 64-69.

10. I wish to emphasize that this essay is critical rather than synthetic. That is, it sets forth counterarguments to the arguments made by the New Federalists and attempts to show that their arguments are unpersuasive. But even assuming that the essay successfully makes its case, that does not establish that the conclusions drawn by the New Federalists are incorrect, only that they are poorly supported. 


\section{The New Federalism}

\section{A. The Origins of the New Federalism}

The New Federalism did not emerge full-grown in the 1994 Term. Instead, it was an outgrowth of conservative jurists' and scholars' continuing concern over federal invasions of state prerogatives.

This concern surfaced dramatically two decades before Lopez in National League of Cities $v$. Usery, ${ }^{11}$ which, like Lopez, was authored by Chief Justice Rehnquist. With Justice Blackmun providing the somewhat unenthusiastic fifth vote, Justice Rehnquist held that applying the federal minimum wage to certain state employees unconstitutionally invaded the "attributes of sovereignty attaching to every state government."12 In Hodel v. Virginia Surface Mining \& Reclamation Assn., ${ }^{13}$ the Court articulated a three-part test based on League of Cities, which it then applied to uphold federal regulation of strip mining. According to Hodel, to be struck down for exceeding congressional power, a statute must regulate the "States as States," it must "address matters that are indisputably "attribute[s] of state sovereignty," "and it must directly impair " "integral operations in areas of traditional governmental functions." "14 Note the emergence of two themes of the New Federalism: reverence toward state sovereignty and protectiveness toward traditional state functions. ${ }^{15}$

The Hodel test, in practice, proved fatal to state claims of immunity. Following Hodel, the Court unanimously held that federal regulation of state-owned railroads "does not impair a state's ability to function as a state."16 Then, the Court narrowly upheld a federal statute requiring state utility commissions to consider certain methods of energy conservation. ${ }^{17}$ Finally, a closely divided Court upheld the application to state park employees of a federal ban on compulsory retirement. ${ }^{18}$

11. 426 U.S. 833 (1976).

12. 426 U.S. at 845 .

13. 452 U.S. 264 (1981).

14. 452 U.S. at $287-88$ (citations omitted).

15. In a concurring opinion, Justice Rehnquist suggested - ominously, in retrospect that the Court should give more serious consideration to whether congressional regulation, even of private parties, falls within the Commerce Clause. 452 U.S. at 310.

16. United Transp. Union v. Long Island R.R., 455 U.S. 678, 686 (1982).

17. See Federal Energy Regulatory Commn. v. Mississippi, 456 U.S. 742 (1982).

18. The Court agreed that park management is a traditional state function but held that the third prong of Hodel was not met because eliminating mandatory retirement would have 
Ultimately - to complete this oft-told story - Justice Blackmun thought better of his vote in League of Cities and wrote the majority opinion in Garcia v. San Antonio Metropolitan Transit Authority, ${ }^{19}$ which overruled League of Cities. The thrust of the Garcia opinion is that the Constitution indeed does presume the existence of independently functioning state governments but that the primary safeguard against federal interference is structural. ${ }^{20}$

Justice O'Connor's dissent in Garcia broached a theme that was to figure heavily in later New Federalist opinions. She argued that the Framers viewed the commerce power as "important but limited, and expected that it would be used primarily if not exclusively to remove interstate tariffs and to regulate maritime affairs and largescale mercantile enterprise." 21 To protect the basic federal scheme in an era when interstate commerce has mushroomed, Justice O'Connor suggested, the Court needed to defend at least the internal operations of the state government from federal regulation.

Commentators generally assumed, as Justice O'Connor had, the validity of the general expansion of federal legislative power. The problem was to protect the independent policymaking role of the states in a world in which the threat of federal preemption was, by common agreement, virtually omnipresent.22 Among other possibilities, the Guarantee Clause was invoked as a basis for this process-based protection for states' rights. ${ }^{23}$

Despite League of Cities and the Garcia dissent, states' rights had not been a particularly prominent part of conservative jurisprudence. No less a conservative than Robert Bork had represented the federal government in League of Cities: ${ }^{24}$ Even in 1982, such

only a marginal effect on the state's ability to operate its parks efficiently. See EEOC v. Wyoming, 460 U.S. 226 (1983).

19. 469 U.S. 528 (1985).

20. This argument stems from Herbert WeCHSLER, The Political Safeguards of Federalism, in PRINCIPLEs, Polmitics, AND Fundamental LAw 49-82 (1961). For a somewhat skeptical appraisal of this argument, see Larry Kramer, Understanding Federalism, 47 VAND. L. REV. 1485 (1994).

21. 469 U.S. at 583.

22. See Deborah Jones Merritt, The Guarantee Clause and State Autonomy: Federalism for a Third Century, 88 Colum. L. Rev. 1 (1988); Andrzej Rapaczynski, From Sovereignty to Process: The Jurisprudence of Federalism After Garcia, 1985 SuP. CT. REv. 341.

23. See Charles L. Black, Jr., On Worrying About the Constitution, 55 U. CoLo. L. REv. 469 (1984); Merritt, supra note 22. Note that Merritt does not want to contract federal regulatory power, only to maintain "republican" state governments.

24. Bork argued the case as Solicitor General. See National League of Cities v. Usery, 426 U.S. 833, 834 (1976). But see Robert H. Bork, The TEMPtING OF AMERICA: The POLITICAL SEDUCTION OF THE LAW 184 (1990) (arguing that the Tenth Amendment guarantees federalism). 
prominent conservatives as Charles Fried and Antonin Scalia were notably unenthusiastic about states' rights. ${ }^{25}$ Fried suggested that the seeds of the current federal dominance may have been present from the beginning, ${ }^{26}$ while Scalia's peroration took an unabashedly nationalist stand: "I urge you, then - as Hamilton would have urged you - to keep in mind that the federal government is not bad but good. The trick is to use it wisely." 27

In the late 1980s, however, some conservative theorists began to take a more vigorous stance in defense of the states. Raoul Berger continued his campaign for unadulterated originalism with a book on federalism. ${ }^{28}$ Berger's book anticipates the later views of Justice Thomas on several key points: that the states predated the federal government and retained their separate sovereign existence after ratification; 29 that the Commerce Clause extends only to trade across state lines; ${ }^{30}$ and that the Supreme Court's Commerce Clause doctrines are ripe for reevaluation. ${ }^{31}$ Similarly, Richard Epstein argued that "the Ford Motor Company did not manufacture goods in interstate commerce, but the Northern Pacific Railroad shipped them in interstate commerce."32 Epstein concluded in no uncertain terms that the Commerce Clause should be limited to "interstate transportation, navigation and sales, and the activities closely incident to them. All else should be left to the states." 33 A third effort to rethink federalism took a markedly less radical tone. In a review of Berger's book, Michael McConnell attempted to make the intellectual case for federalism. ${ }^{34} \mathrm{He}$ stressed the potential practical benefits of federalism but gave more emphasis to the role of federalism in protecting individual rights and preserving local self-rule. ${ }^{35}$

25. See Charles Fried, Federalism - Why Should We Care?, 6 HARv. J.L. \& PuB. Poly. 1 (1982); Antonin Scalia, The Two Faces of Federalism, 6 HARv. J.L. \& PuB. Poly. 19 (1982).

26. See Fried, supra note 25 , at 2.

27. Scalia, supra note 25 , at 22.

28. See Raoul Berger, Federalism: The Founders' Design (1987).

29. See id. at 32-34.

30. See id. at 125 .

31. See id. at 166-70. Notably, Berger does concede that it is probably impractical to root out all of the federal regulatory structure that has accumulated over the decades, but at least a freeze on further expansion, if not some pruning, is required. See id. at 178-80.

32. Richard A. Epstein, The Proper Scope of the Commerce Power, 73 VA. L. REv. 1387, 1442 (1987).

33. Id. at 1454.

34. See Michael W. McConnell, Federalism: Evaluating the Founders' Design, 54 U. CHI. L. REV. 1484 (1987) (book review). For contrary arguments, see Edward L. Rubin \& Malcolm Feeley, Federalism: Some Notes on a National Neurosis, 41 UCLA L. REv. 903 (1994).

35. See McConnell, supra note 34, at 1500-07. 
It was only in the early 1990s that the conservative Justices returned to the task of reinvigorating federalism. The opening salvo was Justice O'Connor's opinion for the Court in Gregory $v$. Ashcroft. ${ }^{36}$ The issue in Gregory was whether the ADEA ${ }^{37}$ applied to certain state judges. Justice O'Connor took advantage of the occasion to delve into the theory of federalism. ${ }^{38}$ The principal benefit of the "constitutionally mandated balance of power" 39 between the two levels of government is that it prevents government abuse and protects individual liberty:

If this "double security" is to be effective, there must be a proper balance between the States and the Federal Government. These twin powers will act as mutual restraints only if both are credible. In the tension between federal and state power lies the promise of liberty.

The Federal Government holds a decided advantage in this delicate balance: the Supremacy Clause. As long as it is acting within the powers granted it under the Constitution, Congress may impose its will on the States. Congress may legislate in areas traditionally regulated by the States. This is an extraordinary power in a federalist system. ${ }^{40}$

Although Gregory was purportedly only a statutory interpretation case, ${ }^{41}$ its constitutional overtones were clear.

Justice O'Connor had the opportunity to apply her theory in a purely constitutional setting in New York v. United States. ${ }^{42}$ Reinforcing her discussion of the values of federalism in Gregory, Justice O'Connor ruled that direct federal coercion of states can never be allowed, regardless of the strength of the government's regulatory interest. ${ }^{43}$ This holding, notably, elevates state sovereignty over

36. 501 U.S. 452 (1991).

37. See Age Discrimination in Employment Act of 1967, Pub. L. No. 90-202, 81 Stat. 602 (codified as amended at 29 U.S.C. $\$ \S 621-34$ (1988)).

38. Describing the states and the federal government as "joint sovereigns," she argued that this structure "assures a decentralized government that will be more sensitive to the diverse needs of a heterogenous society; it increases opportunity for citizen involvement in democratic processes; it allows for more innovation and experimentation in government; and it makes government more responsive by putting the States in competition for a mobile citizenry." 501 U.S. at 458 (citing McConnell, supra note 34, at 1493-500, and Merritt, supra note 22 , at 3-10).

39. 501 U.S. at 458 (citations omitted).

40. 501 U.S. at 459-60 (citation omitted). Note Justice O'Connor's obvious discomfort with the Supremacy Clause, which she apparently considers somewhat at odds with her idea of a normal federalist system.

41. Based on this vision of federalism, the Court held that it would construe a federal statute to regulate the qualifications of state officials only if it was unambiguously required by a plain statement to that effect - a statement that was lacking in Gregory. See 501 U.S. at 470.

42. 505 U.S. 144 (1992).

43. At issue was whether Congress could force states to establish programs for disposing of low-level radioactive waste, at penalty of "taking title" to the waste if they failed to enact 
such less substantial interests as racial equality and freedom of speech, both of which can be impaired on the basis of a sufficiently compelling government interest.

\section{B. The New Federalism Comes of Age}

In 1995, the New Federalism broke out of the limited area of state immunity. Each of the recent opinions - the Term Limits dissent and the majority and concurring opinions in Lopez - elaborates on different aspects of the New Federalism and deserves individual attention.

Chief Justice Rehnquist's opinion for the Court in Lopez is predominantly doctrinal. At the outset, however, Chief Justice Rehnquist does advert to "first principles." Relying on Madison's characterization of federal powers as "few and defined" while state powers are "numerous and indefinite," Justice Rehnquist then quoted from Gregory about the role of this division of powers in preserving liberty. ${ }^{44}$ Admittedly, he added, the scope of federal power had greatly increased in the post-New Deal era, partly because of the "great changes" in the economy and partly because of a desire to eliminate what were considered artificial restraints on federal power. ${ }^{45}$ Having analyzed the post-New Deal case law, however, Justice Rehnquist concluded that the school gun law at issue in Lopez ${ }^{46}$ did not fall squarely within the previously recognized scope of congressional power. He declined to expand that scope any further.

The concurring opinions have more theoretical substance. Justice Kennedy, joined by Justice O'Connor, reiterated the Gregory vision of federalism as a protection for individual liberty. ${ }^{47}$ The statute before the Court, he concluded, "upsets the federal balance to a degree that renders it an unconstitutional assertion of the commerce power."48 Justice Kennedy's concurrence suggests that the Court should preserve the current balance between the states and

such a program on schedule. See 505 U.S. at 174-77. The statute is obviously designed to deal with the NIMBY syndrome (Not in My Back Yard): every state wanted to generate lowlevel waste in local medical facilities, but every state wanted some other state to take the responsibility for providing a site for disposal. For an argument in favor of upholding the statute, see Evan H. Caminker, State Sovereignty and Subordinacy: May Congress Commandeer State Officers to Implement Federal Law?, 95 CoLum. L. REv. 1001 (1995).

44. See United States v. Lopez, 115 S. Ct. 1624, 1626 (1995).

45. See 115 S. Ct. at 1628.

46. See 18 U.S.C. $\$ 922(q)$ (1994).

47. See $115 \mathrm{~S}$. Ct. at 1638-39.

48. 115 S. Ct. at 1640. 
the federal government rather than begin a rollback of federal power. ${ }^{49}$ Justice Kennedy concluded that the statute intruded on state sovereignty and that, in the absence of a stronger link with commercial concerns, "that interference contradicts the federal balance the Framers designed and that this Court is obliged to enforce."so

If Justice Kennedy offered qualified support for the majority, Justice Thomas clearly believed that the majority had not gone far enough. Like Epstein and Berger, ${ }^{51}$ he argued that modern Commerce Clause jurisprudence is almost wholly illegitimate. His analysis rests on two premises. First, commerce consists only of sales transactions and transportation in connection with those transactions. ${ }^{52}$ Second, agriculture, manufacturing, and most other areas of life should be subject only to state regulation. ${ }^{53}$ Epstein and Berger, who had seemed far outside the mainstream a few years before, now had the solid support of at least one Justice.

Maybe more than just one: Justice Thomas's dissent in the Term Limits case was equally audacious, but here he spoke for four Justices. Term Limits involved a state's power to set term limits for members of Congress. The majority view was that this power pertained solely to the new government created by the Constitution rather than to any preexisting state authority. Hence, the majority said, this power was not "reserved" by the Tenth Amendment. In the course of this discussion, Justice Stevens's majority opinion explains the conventional view of state and federal sovereignty. Under the Articles of Confederation, "the States retained most of their sovereignty, like independent nations bound together only by

49. See $115 \mathrm{~S}$. Ct. at 1638-39 (stating that citizens need to be able to identify those responsible for government action and should be able to rely on the traditional boundaries between the activities of federal and state governments); $115 \mathrm{~S}$. Ct. at 1640 (claiming that the gun control Act was objectionable because it invades a traditional area of state regulation, education).

50. $115 \mathrm{~S}$. Ct. at 1642.

51. See supra notes $28-33$ and accompanying text.

52. See $115 \mathrm{~S}$. Ct. at $1643-44$.

53. According to Justice Thomas, the exchanges during the ratification campaign reveal the relatively limited reach of the Commerce Clause and federal power:

The Founding Fathers confirmed that most areas of life (even many matters that would have substantial effects on commerce) would remain outside the reach of the Federal Government. Such affairs would continue to be under the exclusive control of the States.

... [D] [Dpite being well aware that agriculture, manufacturing, and other matters substantially affected commerce, the founding generation did not cede authority over all these activities to Congress. Hamilton, for instance, acknowledged that the Federal Government could not regulate agriculture and like concerns ....

$115 \mathrm{~S}$. Ct. at 1645. 
treaties," "but the new Constitution "reject[ed] the notion that the Nation was a collection of States, and instead creat[ed] a direct link between the National Government and the people of the United States."54 A patchwork of local qualifications for federal office, Justice Stevens argued, would "sever the direct link that the Framers found so critical between the National Government and the people of the United States."55

Justice Thomas's dissent squarely rejects this vision of national sovereignty: "Because the majority fundamentally misunderstands the notion of 'reserved' powers, I start with some first principles." 56 The most basic of these first principles, according to Justice Thomas, is this: "The ultimate source of the Constitution's authority is the consent of the people of each individual State, not the consent of the undifferentiated people of the Nation as a whole."57 Despite the adoption of the Constitution, "the people of each State retained their separate political identities." 58 Even in language where others have found an affirmation of national unity, Justice Thomas found a reaffirmation of the fundamental status of the states as compared with the Nation:

The ringing initial words of the Constitution - "We the People of the United States" - convey something of the same idea. (In the Constitution, after all, "the United States" is consistently a plural noun.") The Preamble that the Philadelphia Convention approved before sending the Constitution to the Committee of Style is even clearer. It began: "We the people of the States of New-Hampshire, Massachusetts, Rhode-Island and Providence Plantations, Connecticut, New-York, New-Jersey, Pennsylvania, Delaware, Maryland, Virginia, North-Carolina, South-Carolina, and Georgia . ..." Scholars have suggested that the Committee of Style adopted the current language because it was not clear that all the States would actually ratify the Constitution. 59

In short, Justice Thomas said, the concept of popular sovereignty underlying the Constitution "tracks" rather than erases state lines. 60 He found it senseless to interpret the Tenth Amendment as reserving powers to the "undifferentiated people of the Nation as a whole, because the Constitution does not contemplate that those

54. Term Limits, $115 \mathrm{~S}$. Ct. at 1855 (citations omitted).

55. $115 \mathrm{~S}$. Ct. at 1864 .

56. $115 \mathrm{~S}$. Ct. at 1875 .

57. $115 \mathrm{~S}$. Ct. at 1875.

58. $115 \mathrm{~S}$. Ct. at 1877.

59. $115 \mathrm{~S}$. Ct. at $1876 \mathrm{n} .1$ (citations omitted). Following Justice Thomas's interpretation, a more accurate wording might have been, "We the Peoples of the United States."

60. See $115 \mathrm{~S}$. Ct. at 1877. 
people will either exercise power or delegate it. The Constitution simply does not recognize any mechanism for action by the undifferentiated people of the Nation."61

Justice Kennedy, who had provided the crucial fifth vote in Lopez, refused to go along with Justice Thomas's view of state sovereignty in Term Limits. In his view, the heart of the legitimacy of the federal government is "that it owes its existence to the act of the whole people who created it."62 Although the Framers, in his view, were "solicitous of the prerogatives of the States," the states could not be allowed to interfere with the exercise of federal powers or with "the most basic relation between the National Government and its citizens, the selection of legislative representatives."63

To summarize, the New Federalism has three major premises. The first tenet is that the states retain crucial aspects of sovereignty. Sovereignty is a concept we usually identify with independent nations. ${ }^{64}$ To attribute sovereignty to the states is in some degree to assign them some aspect, if only residual, of nationhood. In the strongest version, that espoused by Raoul Berger and the four Term Limits dissenters, the sovereignty of the states is actually primary. The states came before the federal government, and they remain more fundamental to the constitutional scheme than the federal government, which is a creature of the separate peoples of the individual states. A weaker version of this premise is that state sovereignty coexists with federal sovereignty.

The second tenet derives from the recognition that, under the Supremacy Clause, federal power prevails where federal and state power overlap. Hence, if the states are to have some form of sovereignty, they must have some sphere of exclusive power or, at the very least, a sphere that the federal government can only enter under special circumstances. In the older version of the New Federalism - from League of Cities through Gregory - that separate

61. 115 S. Ct. at 1877.

62. $115 \mathrm{~S}$. Ct. at 1872 ; see also $115 \mathrm{~S}$. Ct. at 1873.

63. $115 \mathrm{~S}$. Ct. at 1873 . As this disagreement between Justice Kennedy and the other members of the conservative wing of the Court indicates, the New Federalism is not a monolith. Interestingly enough, Justice Kennedy's arguments are very similar in structure to John Marshall's arguments about the Commerce Clause. Felix Frankfurter wrote that "Marshall's use of the commerce clause greatly furthered the idea that though we are a federation of states we are also a nation, and gave momentum to the doctrine that state authority must be subject to such limitations the Court finds it necessary to apply for the protection of the national community." Felix Frankfurter, The Commerce Clause Under Marshall, TANEY AND WHITE 18-19 (1937).

64. See Rapaczynski, supra note 22 , at $349-50$ (explaining that the least problematic example of sovereignty is an independent nation; the use of the concept of sovereignty in federalism discussions derives from this paradigm case). 
sphere was the internal operation of the state government. The various majority Justices in Lopez made different efforts to redefine the state sphere. Chief Justice Rehnquist essentially defined it by exclusion and claimed that the state sphere consisted of all areas that are not assigned to the federal government. In turn, he defined federal competence to cover three broad categories: regulation of the channels of interstate commerce; protection of interstate instrumentalities even from intrastate interference; and control of economic activities "having a substantial relation to interstate commerce." 65 Justices Kennedy and O'Connor defined the sphere of presumptive state autonomy as consisting of noncommercial activities traditionally regulated by the states. ${ }^{66}$ Taking the broadest view of state sovereignty, Justice Thomas set aside regulation of manufacturing and agriculture for the states along with jurisdiction over all activities other than the interstate sale and shipment of goods.

Finally, the New Federalism holds that the states are not merely a structural feature of our governmental system but an important affirmative good in need of protection. For the New Federalists, the states are not simply a fact of life in our democracy. Rather, in the suggestive words of Robert Nagel, federalism is a fundamental value. ${ }^{67}$ In particular, in order to safeguard individual liberty, the Court must maintain the balance of power between the states and the federal government. ${ }^{68}$

\section{The Washington Letter and the Debate Over Constirututional METHOdOLOGY}

The New Federalists claim their ideas represent the first principles of federalism, and so it is natural to investigate the understanding of the Framers on this point. This historical inquiry is, as we will see, a matter of some difficulty.

\section{A. The Washington Letter}

Before we begin to ponder its legal significance, a close look at the letter itself is in order. With a few minor exceptions, the Constitution we have today is the draft produced by the Committee on Style. Along with the penultimate draft of the Constitution, the

65. United States v. Lopez, 115 S. Ct. 1624, 1629-30 (1995).

66. See 115 S. Ct. at 1640-42.

67. See Robert F. Nagel, Federalism as a Fundamental Value: National League of Cities in Perspective, 1981 Sur. CT. REv. 81.

68. See id. at 88; see also text accompanying notes $36-42$. 
Committee was also charged with producing a cover letter. The Committee was small but distinguished: it consisted of Madison, Hamilton, Gouverneur Morris, Rufus King, and the Chair, William Samuel Johnson. Thus, if nothing else, the cover letter represented an effort by some of the Convention's most distinguished members to explain the nature of the final product. Indeed, because the letter was approved unanimously, paragraph by paragraph, and so far as we are aware, without debate, we must assume it reflects the views of the delegates generally about the nature of their work, at a time very close to the end of the process. ${ }^{69}$ It was, in short, a consensus document, signed by George Washington as President of the Convention "by unanimous Order of the Convention."

Apart from some obligatory flourishes at the beginning and end of the letter, it consists of four significant paragraphs. The first of these substantive paragraphs ${ }^{70}$ begins with a remark on the need to empower the federal government: "The friends of our country have long seen and desired, that the power of making war, peace, and treaties, that of levying money and regulating commerce, and the correspondent executive and judicial authorities should be fully and effectually vested in the general government of the Union."71 Because of the "impropriety" of entrusting "such extensive trust to one body of men," the letter continues, necessity demanded a "different organization" - presumably meaning the separation of powers.

The next paragraph addresses the status of the states. "It is obviously impracticable in the federal government of these states, to secure all rights of independent sovereignty to each, and yet provide for the interest and safety of all: Individuals entering into society, must give up a share of liberty to preserve the rest."72 The "magnitude of the sacrifice," we are told, depends on the circumstances; the line between surrendered and reserved rights is always difficult to draw with precision, and the difficulty was increased here by the diverse situations of the various states.

The next two paragraphs stress the imperative of a strong government and the need for compromise in attaining that end. "In all our deliberations," the delegates informed their fellow citizens, "we

69. See James Madison, Notes of Debates in the Federal Convention of 1787, at 626 n.30 (1966).

70. This is actually the second paragraph in the letter; the first is in the nature of a courtly salutation.

71. See app. at 649.

72. See id. 
kept steadily in our view, that which appears to us the greatest interest of every true American, the consolidation of our Union, in which is involved our prosperity, felicity, safety, perhaps our national existence."73 As a result, the states were willing to give way at the Convention on points of "inferior magnitude," in a spirit of magnanimity and compromise. Although they recognized that no one was likely to like all aspects of the final product, the delegates hoped to have minimized objections to the extent possible, and it was their "most ardent wish" that the Constitution would "promote the lasting welfare of that country so dear to us all, and secure her freedom and happiness." 74

With that, in less than two printed pages, the Washington letter is over, except for a flowery signature line dubbing the delegates the "most obedient and humble servants" of the addressee, "His Excellency the President of Congress." The letter was duly transmitted to Congress and then by Congress to the state legislatures, along with the text of the Constitution.

\section{B. The Interpretation Wars}

After its transmission to the states, the Washington letter seemingly vanished from the annals of history. The reasons for resurrecting it stem from recent debates over legal interpretation.

One battleground has involved statutory interpretation. In recent decades, statutory interpretation usually has involved an eclectic mix of reliance on text, statutory purpose, public policy, and legislative history. ${ }^{75}$ In the $1980 \mathrm{~s}$, formalists mounted a challenge to this conventional approach in favor of a much more restrictive method of interpretation. ${ }^{76}$ As Bill Eskridge explains, "[f]ormalism posits that judicial interpreters can and should be tightly constrained by the objectively determinable meaning of a statute; if unelected judges exercise much discretion in these cases, democratic governance is threatened." 77 Judge Easterbrook states: "Laws are designed to bind, to perpetuate a solution devised by the enacting legislature, and do not change unless the legislature affirm-

73. See id.

74. See app. at 650.

75. For a fuller discussion, see William N. Eskridge, Jr. \& Philip P. Frickey, Statutory Interpretation as Practical Reasoning, 42 STAN. L. REv. 321 (1990).

76. See, e.g., Frank H. Easterbrook, Text, History, and Structure in Statutory Interpretation, 17 Harv. J.L. \& PuB. Poly. 61 (1994).

77. William N. Eskridge, Jr., The New Textualism, 37 UCLA L. REv. 621,646 (1990). 
atively enacts something new... . Law does not change in meaning as the political culture changes."78

According to formalists, legislative history should be consulted only under very limited circumstances. It is normally irrelevant because "the law" consists of the statute Congress passed, not the ideas in the minds of the legislators. ${ }^{79}$ Furthermore, authorizing the use of legislative history simply empowers judges to enact their own policy choices at the expense of the statutory language ${ }^{80}$ and allows individual legislators to make law without obtaining the full support of their colleagues.81 Additionally, formalists maintain, the ideas of legislative purpose and legislative intent are incoherent. A legislature is a collective body, whose members are often in disagreement and have no cogent set of preferences. Legislation is often a compromise between opposing interests whose only purpose is to strike a deal. "Legislation is compromise. Compromises have no spirit; they just are." 82 Hence, when the legislature has failed to speak clearly on an issue, it is useless for a court to try to fill the gap by consulting the "spirit" of the statute.

The conservative critique of legislative intent raises obvious questions about the appropriate role of original intent in constitutional cases as well. Space does not permit a full discussion of the ongoing debate about originalism, but a review of some of its highlights will be useful in assessing the significance of the Washington letter.

Evidence of original intent has always played a role in constitutional adjudication. In the 1980 s, conservative scholars argued that original intent should be the key factor in interpretation. This view was widely publicized as a result of speeches by then-Attorney General Edwin Meese ${ }^{83}$ and then received even greater attention as a result of the Bork confirmation hearings. ${ }^{84}$ Today, as his opinions

78. Easterbrook, supra note 76, at 69.

79. See id. at 65-66.

80. See INS v. Cardoza-Fonseca, 480 U.S. 421, $452-53$ (1987) (Scalia, J., concurring); Kenneth W. Starr, Observations about the Use of Legislative History, 1987 DukE L.J. 371, 376.

81. See W. David Slawson, Legislative History and the Need to Bring Statutory Interpretation Under the Rule of Law, 44 STAN. L. REV. 383, 397-98 (1992).

82. Easterbrook, supra note 76 , at 68.

83. For discussion of the early phases of this debate, see Murray Dry, Federalism and the Constitution: The Founders' Design and Contemporary Constitutional Law, 4 Const. ComMENT. 233, 233-34 (1987).

84. See Bork, supra note 24 , at 300-01. For a summary of the arguments for originalism, see Earl M. Maltz, The Failure of Attacks on Constitutional Originalism, 4 Consr. Comment. 46-56 (1987). 
in Term Limits and Lopez illustrate, Justice Thomas seems to be the most aggressive practitioner of originalism on the Court. ${ }^{85}$

There are two basic normative arguments for originalism: first, that it is the only way to reconcile judicial review with majority rule and, second, that intent is the basis for interpreting all legal documents, of which the Constitution is only one. The first argument was nicely put by former Attorney General Meese:

The Constitution represents the consent of the governed to the structures and powers of the government. The Constitution is the fundamental will of the people; that is the reason the Constitution is the fundamental law. To allow the courts to govern simply by what it views at the time as fair and decent, is a scheme of government no longer popular; the idea of democracy has suffered. ${ }^{86}$

As John Hart Ely has explained, originalism also coheres with an idea about legal interpretation that has wide currency in our legal culture: it "fits our usual conceptions of what law is and the way it works." 87 In construing a statute, Ely says, "a court obviously will limit itself to a determination of the purposes and prohibitions expressed by or implicit in its language." 88 We "might even consider a call to the lunacy commission" if a judge goes beyond the language of the statute "to enforce, in the name of the statute in question, those fundamental values he believe[s] America ha[s] always stood for." 89 As Michael McConnell has argued, just as we look to original intent when interpreting contracts and wills, so we should do so when interpreting the Constitution. ${ }^{90}$ In short,

85. See United States Term Limits, Inc. v. Thomton, 115 S. Ct. 1842, 1875-914 (1995) (Thomas, J., dissenting); United States v. Lopez, 115 S. Ct. 1624, 1642-51 (1995) (Thomas, J., concurring); see also Rosenberger v. Rector \& Visitors of Univ. of Va., $115 \mathrm{~S}$. Ct. 2510, 252844 (1995) (Thomas, J., concurring); McIntyre v. Ohio Elections Comm., 115 S. Ct. 1511, $1525-$ 30 (1995) (Thomas, J., concurring in the judgment).

86. See Edwin Meese, III, The Supreme Court of the United States: Bulwark of a Limited Constitution, 27 S. TEx. L. REv. 455, 465 (1986). Robert Bork eloquently reiterated this view in his confirmation hearing: "If a judge abandons intention as his guide, there is no law available to him and he begins to legislate a social agenda for the American people." Bork, supra note 24 , at 300 . In response to this argument, critics of originalism have questioned whether majoritarianism should be considered our exclusive fundamental norm; whether the adoption of the Constitution itself met the requirements of that norm as we currently understand it; and whether in fact the judicial branch should be considered less democratic than the legislature as a source of evolving social norms. For a survey of these arguments, see Daniel A. Farber \& Suzanna Sherry, A History of the American Constitution 386-88 (1990).

87. John Hart Ely, Democracy and Distrust: A Theory of Judicial Review 3 (1980).

88. Id.

89. Id.

90. See Michael W. McConnell, The Role of Democratic Politics in Transforming Moral Convictions into Law, 98 Y ALE L.J. 1501, 1525 (1989) (book review) (arguing that originalism is essentially the method used to interpret statutes, contracts, wills, and treaties). 
this argument goes, originalism is simply the normal mode of interpreting all legal documents.

At this point, conservative theorists may appear to be on a collision course with themselves. We saw earlier that conservative theorists have launched a vigorous attack on the use of legislative history in statutory interpretation. How is this compatible with their attachment to originalism in constitutional law? The problem is particularly acute because of their "one size fits all" argument that originalism is the only legitimate method of legal interpretation for statutes, constitutions, and private legal instruments.

Resolving this problem requires a closer look at how conservative theorists define the proper role of intent in both the statutory and constitutional contexts. In the constitutional context, Charles Fried cautions that judges should not consider "intent" a fact about the mental state of each drafter, as if the text itself were a kind of second-best, and we really would "prefer to take the top off the heads of authors and framers - like soft-boiled eggs - to look inside for the truest account of their brain states at the moment that the texts were created."91 Indeed, as Judge Easterbrook has pointed out, such an exercise would be doomed to failure because of the multiple authorship of public documents: "Peer inside the heads of legislators and you find a hodgepodge." 92

Rather than the soft-boiled-egg approach eschewed by Fried and Easterbrook, the more defensible originalist approach to meaning is to formulate it as being objective. As Judge Easterbrook puts it, to determine the meaning of the words used in the text, we must consult its context: "The goals, purposes, concerns, of the authors illuminate things. Intent then informs a reading of the text, tells us its meaning."93 More specifically, that meaning is objective, based on the understanding of the text by a reasonable reader of the time who was familiar with the context. ${ }^{94}$

On this view, then, originalism is not intended to discover the personal views of the drafters of the Constitution or the preferences and expectations of the ratifiers. Instead, it is intended to reveal

91. Charles Fried, Sonnet LXV and the "Black Ink" of the Framers' Intention, 100 Harv.

L. REv. 751, 758-59 (1987).

92. Easterbrook, supra note 76 , at 68 (concluding that for this reason "intent is empty").

93. Id. at 64 .

94. See Oliver Wendell Holmes, The Theory of Legal Interpretation, 12 HARv. L. REv. 417, 417-19 (1898); Gary Lawson, The Rise and Rise of the Administrative State, 107 HARV. L. REv. 1231, 1231 n.1 (1994); McConnell, supra note 90, at 1526-29; Michael Stokes Paulsen, The Most Dangerous Branch: Executive Power to Say What the Law Is, 83 GEo. L.J. 217, 227 n.23 (1994). 
the objective understanding of the text by a reasonable person of the time. That reasonable person, in addition to other contextual knowledge, is also assumed to be aware of the "goals, purposes, and concerns of the authors" to the extent that such information was publicly available. 95 Interpretation of statutes is directed at ascertaining the same kind of objective meaning, thus eliminating the disparity between constitutional originalism and statutory formalism. ${ }^{96}$

The remainder of this essay attempts to apply this methodology to the New Federalism, using the Washington letter as a fulcrum. There are two reasons for this choice of methodology. First, it is the most coherent and defensible statement of the favored conservative approach to interpretation. It seems appropriate to apply this interpretative approach to the predominant conservative theory of federalism. Second, even for nonoriginalists, the original understanding has some bite. The nonoriginalist also may want to consult other historical materials for whatever light they shed on our traditions and aspirations as a society, but those tied most directly to the historic meaning of the text have a special claim to our attention.

\section{The Washington Letter and Conservative Theories of Interpretation}

This formulation of originalism has the drawback of intensifying some of the practical problems of implementing an originalist program of interpretation. As no lesser light than Justice Scalia has told us:

[I]t is often exceedingly difficult to plumb the original understanding of an ancient text. Properly done, the task requires the consideration of an enormous mass of material - in the case of the Constitution and its Amendments, for example, to mention only one element, the records of the ratifying debates in all the states. Even beyond that, it requires an evaluation of the reliability of that material .... And further still, it requires immersing oneself in the political and intellectual atmosphere of the time .... It is, in short, a task sometimes better suited to the historian than the lawyer. ${ }^{97}$

95. See, e.g., Easterbrook, supra note 76, at 64.

96. The problem of defining the "reasonable reader" and setting the parameters for her knowledge of context is not at all a trivial one, but this formulation does at least provide a coherent basis for some more elaborate theory of originalist interpretation.

97. Antonin Scalia, Originalism: The Lesser Evil, 57 U. CrN. L. REv. 849, 856-57 (1989). Some of the difficulties encountered by even extremely capable legal scholars are explored in Martin S. Flaherty, History "Lite" in Modern American Constitutionalism, 95 Colum. L. REv. 523 (1995). 
Given this mass of material, one faces an unavoidable temptation to "look over a crowd and pick out your friends."98 As Judge Easterbrook has said about the quest to locate clues about meaning in legislative history:

A Sherlock Holmes could work through the clues, and those most reliable, and draw unerring inferences. Alas, none of us is a worthy successor to Holmes .... We hear in the debates what we prefer to hear - and our preferences differ widely. Even when all of us hear the same thing, a search for these clues consumes resources but does not yield rewards comparable to the effort invested. ${ }^{99}$

Hence, Judge Easterbrook says, judges must eschew an excessively nuanced approach in order to avoid unacceptable process and error costs. ${ }^{100}$

The unreliability of some of the basic source materials further complicates the originalist task. There have been recurring charges that Madison later altered his notes, perhaps to reflect his own changing constitutional views. After a careful investigation, based on such matters as the watermarks on Madison's paper, historian James Hutson has concluded that any alterations were not significant. ${ }^{101}$ But Hutson points out that Madison gave only a highly abbreviated account of the debates, probably reporting less than onetenth of what was said.102

Hutson points out even more severe problems with other parts of the documentary record. He concludes that the records of the ratification debates are too corrupt to be relied upon. For example, the Pennsylvania and Maryland debates were recorded by ardent Federalist Thomas Lloyd, who was paid by the Federalists to delete all of the Antifederalists' speeches. He reported only selected Fed-

98. See Conroy v. Aniskoff, 113 S. Ct. 1562, 1567 (1993) (Scalia, J., concurring in the judgment). Similarly, Felix Frankfurter warned about the dangers of trying to glean "trends in American constitutional history" from judicial opinions coupled with other historical evidence. Also, the risk of ripping a textual comment from its historical context and reading in a more lasting significance is great. See FrANkFuRTER, supra note 63, at 9 ("We must be on our guard against over-sophistication, and not find luminous, deeply conceived, rational processes where there is only tentative, groping, obscure empiricism, or the instinctive and only half conscious response of habituation to a concrete controversy.").

99. Easterbrook, supra note 76, at 61 (footnotes omitted).

100. See id. at 70.

101. See James H. Hutson, The Creation of the Constitution: The Integrity of the Documentary Record, 65 TEXAS L. REv. 1, 24-33 (1986).

102. Madison averaged about 2700 words per session in June, which is only about seven percent of the probable number of words spoken in each five-hour session. See id. at 34. The notes also seem to give particular attention to Madison's own remarks, a tendency that is understandable but which biases our knowledge of the debates. It also would not be surprising if he sometimes failed to resist the temptation to improve upon the oral version of his remarks when compiling the final written version. See id. at 35. 
eralist speeches and even those seem to have been significantly revised. ${ }^{\text {103 }}$

We do possess voluminous printed matter from the ratification period, including most notably the Federalist Papers. ${ }^{104}$ These documents do not necessarily reflect the reasonable understanding of the text at the time it was written. The problems resemble those that formalists have described as affecting legislative debates: "The goal of each legislator is to create an expression, or at least an impression, of the legislative intent on any points of interest to him or her."105 Thus, as in evaluating other narratives, the "stories" told by the Framers about the meaning of the Constitution must be evaluated for their typicality and accuracy, for these characteristics reflect the meaning that a reasonable reader would have placed on the document. ${ }^{106}$ A formalist, originalist approach to statutory interpretation requires no less. Yet this task is one that, as Judge Easterbrook and Justice Scalia point out, judges can expect to perform only with difficulty and considerable risk of error.

In many respects, the Washington letter is unique in its relative immunity from these difficulties. First, and most obviously, it is free from the problems of reliability that plague the records of the debates of the Philadelphia and ratification conventions. It is an official written document - indeed, the only explanation ever issued in any official form prior to ratification regarding the meaning of the Constitution. What it says may or may not be significant, but, at least, we need entertain no doubt about its actual content. This in itself makes the Washington letter far more useful than the ratification debates and, to a lesser degree, than Madison's notes.

Second, the letter is less prone to disputes about typicality than other ratification-related documents. Hamilton and Madison, the primary authors of the Federalist Papers, were members of the small committee that drafted the letter, so we can be confident that it reflects their views. But it also reflects the views of the other members of that committee, George Washington, who signed it, and the remaining delegates, considering that it was unanimously approved without debate after a paragraph-by-paragraph review. As an official document, the Washington letter has the advantage of a formal process of enactment. Neither individual remarks at the

103. See id. at 22-23.

104. See id. at 12-24.

105. Slawson, supra note 81 , at 396.

106. See Daniel A. Farber \& Suzanna Sherry, Telling Stories Out of School: An Essay on Legal Narratives, 45 StaN. L. REv. 807 (1993). 
Convention nor the various documents produced during the ratification period were subject to this process of deliberation and approval before they were issued.

Third, the Washington letter is less prone than other sources to problems of conscious or unconscious distortion by its authors. To begin with, it was designed for a nationwide audience, so the authors would have been unable to tailor it to the exigencies of the ratification process in particular states. Because the ratification process had not yet begun, they were faced with a "veil of ignorance" about the politics of ratification and would have found it somewhat more difficult to doctor their expressed interpretation of the Constitution in a play for political support.

Finally, the Washington letter has the virtues of its defects, those defects being its brevity and its historical obscurity. The letter was carefully considered at the Convention and then disseminated to the states in connection with ratification, but it never excited any discussion. The simplest explanation for the lack of discussion is that it simply repeated what everyone then - but not necessarily today - already understood. The letter's brevity is also a major virtue, given the time limitations on judges and also the risk that more voluminous documents will be consciously or unconsciously "mined" for material favoring a judge's position.

Thus, if we are to follow the strictures of Judge Easterbrook and Justice Scalia in our use of historical materials, the Washington letter has a virtually unique claim to our attention. It is not only deserving of attention in its own right but very useful in minimizing what Judge Easterbrook calls the process and error costs of utilizing other historical materials ${ }^{107}$ because it provides a handy gauge of their reliability and typicality. We turn, then, to a consideration of the implications of the Washington letter for the debate over the New Federalism.

\section{The Washington Letter and the Tenets of the NEW FEDERALISM}

As we saw in Part II, the New Federalism centers on three propositions: (1) the states retain a - possibly primary - sovereignty; (2) this sovereignty is reflected in the existence of presumptive limits on federal jurisdiction; and (3) the Framers viewed this separation of state and federal power as a guarantee of liberty. These tenets form the basis for the argument that the courts should inter-

107. See supra text accompanying note 100. 
vene to preserve the "balance of federalism" the Framers designed. We will consider these three tenets in order.

\section{A. The Question of Sovereignty}

The original understanding of sovereignty is the kind of historical question that is most difficult for judges to analyze. The concept of sovereignty had great significance for the framing generation and has generated a corresponding amount of interest among historians. 108 Unraveling the meaning of these historical records has proven quite difficult. The Framers' debate was driven by their immediate political interests, which gave them an incentive to distort whatever their true philosophical positions might have been. ${ }^{109}$ Various senses of the word "sovereignty" were not carefully distinguished.110 As one historian puts it, the Framers were "politically multilingual," using a variety of political theories whenever those theories suited their purposes. ${ }^{111}$

We usefully can delineate three views of the sovereignty issues: Pure Nationalism (Lincoln's theory): The colonies declared independence as a collective body, which thereby succeeded to the sovereignty formerly held by the King. This national sovereignty always remained with the federal government throughout a series of governmental reorganizations - first the Articles of Confederation, then the Constitution. 112

Transformational Nationalism: The states retained their separate sovereignty until the adoption of the Constitution, which created a new national sovereign - "E pluribus unum."113

108. For recent discussions by historians, see Samuel H. BeEr, To Make a Nation: THE RedisCOVERY OF AMERICAN FEDERALISM 197- 202, 236, 248-55, 314-15, 320 -28 (1993); RICHARD B. MORRIS, THE FORGING OF THE UNION 1781-1789, at 55-63 (1987); GORDON S. WoOd, The Creation of THE AMERican Republic 1776-1787, at 344-89, $524-36$ (1969).

109. For example, one issue was whether the colonies had declared independence collectively, so that sovereignty at least momentarily reposed in the Continental Congress, or severally, so that it resided in the states at the time of Independence. This seemingly esoteric question had legal implications regarding title to vast disputed areas of land. Under the former theory, western land claimed by Virginia had instead reverted to the Continental Congress at the time of Independence. See Forrest MCDonald, Novus Ordo SeClorum: THE INTELlectual ORIGINS OF tHE Constitution 146 (1985).

110. For a modern effort to do so, see Rapaczynski, supra note 22, at 346-58. For a discussion of the confusion during the framing period, see $\mathrm{H}$. Jefferson Powell, The Political Grammar of Early Constitutional Law, 71 N.C. L. Rev. 949, 985-87 (1993).

111. See MCDonald, supra note 109, at 235.

112. See Michael Kammen, a Machine That Would Go of Itself: The ConstituTION IN AMERICAN CULTURE 109 (1986) (reprinting a Civil War-era constitutional catechism); James M. MCPherson, Battle CRY of Freedom: The Civil War ERA 246.48 (1988); KenNeTH M. StampP, The ERA OF Reconstruction, 1865-1877, at 25-27 (1966).

113. This theory was endorsed, for example, by the majority in the Term Limits case. See United States Term Limits, Inc. v. Thornton, 115 S. Ct. 1842, 1855 (1995); see also Akhil Reed Amar, Of Sovereignty and Federalism, 96 YALE L.J. 1425, 1460 (1987) (arguing that although 
State Populism (Calhoun's theory): During Independence, the people of each state separately became sovereign. When they adopted the Constitution, they retained their separate political existences, but delegated some of their powers to the national government and some to the state governments. 114

As the dispute in the Term Limits case illustrates, there is no consensus about which of these theories provides the best legal fit with the historic facts or which one was the dominant understanding of the framing period. ${ }^{115}$

With respect to this issue, strictures about the dangers of generalist judges attempting to untangle a complex and ambiguous historical record seem especially forceful. The likelihood that busy judges will master the vast amount of historical material is not great. Given this large, complex historical record, a substantial risk exists that judges - or more realistically, their law clerks ${ }^{116}$ - simply will look for friendly faces in the crowd, picking out the historical data that most clearly support their position. Hence, it is wise to follow Judge Easterbrook's advice and reduce process and error costs. ${ }^{117}$ The Washington letter can provide great assistance in this respect because of its strong claim to reliability and typicality. ${ }^{118}$

The Washington letter sheds interesting, though not entirely unambiguous, light on this sovereignty issue. The third paragraph of the letter plainly contemplates some loss of sovereignty by the states and its transfer to the federal government: "It is obviously impracticable in the federal government of these states, to secure

Article VII said the Constitution would go into effect when nine states ratified it, it "confirmed the pre-existing sovereignty of the People of each state by proclaiming that the Constitution would go into effect only between the ... states [that ratified it]." Id. at 1460 . "Once the individual states ratified the Constitution, however, they transferred their sovereignty to the people of the nation." Id.).

114. See Amar, supra note 113, at 1452 \& nn.108-09; see also MCPHERson, supra note 112, at 240; STAMPP, supra note 112, at 25. During the period before the Civil War, southern states justified secession with the theory that the state populace, in adopting the Constitution, had appointed the federal government to act as their agent with regard to certain functions but that such an agency relationship did not transfer sovereignty to the federal government. See David M. PotTer, The Impending Crisis, 1848-1861, at 479 (1976). The people of each state, the theory went, retained the power to nullify the agency relationship by action of a state convention. See id.

115. Compare Justice Thomas's views in his Term Limits dissent, 115 S. Ct. at 1875-77, with those of Justice Kennedy in his concurrence, $115 \mathrm{~S}$. Ct. at 1872 . As to the views of leading modern commentators, see BEER, supra note 108, at 200-02, 236, 320-21 (endorsing the pure nationalism theory); Amar, supra note 113; H. Jefferson Powell, The Oldest Question of Constitutional Law, 79 VA. L. REv. 633, 654-60 (1993). The second theory may have an edge among modern commentators.

116. See Jim Chen, The Mystery and the Mastery of Judicial Power, 59 Mo. L. Rev. 281, 300, 306 (1994).

117. See supra text accompanying notes 99-100.

118. See supra text accompanying note 107. 
all rights of independent sovereignty to each, and yet provide for the interest and safety of all: Individuals entering into society, must give up a share of liberty to preserve the rest."119 Clearly, the states were seen as losing some "rights of independent sovereignty." 120 Moreover, the drafters did not portray the Constitution as merely an agreement between states that retained their separate existence. The letter compares the Constitution with the social compact, which is an irrevocable creation of a unified society - short of circumstances justifying revolution. The implications of this analogy to the social compact later would be discussed in the Federalist Papers:

If individuals enter into a state of society, the laws of that society must be the supreme regulator of their conduct. If a number of political societies enter into a larger political society, the laws which the latter may enact, pursuant to the powers intrusted to it by its constitution, must necessarily be supreme over those societies and the individuals, of whom they are composed. It would otherwise be a mere treaty, dependent on the good faith of the parties, and not a government ....121

Hammering the point home, the fourth paragraph of the Washington letter speaks of the "consolidation of our Union."122 The second paragraph speaks similarly of perfecting "the general government of the Union," which seems to contemplate a degree of political unity, rather than a mere league between entities that retain their own sovereign identities. ${ }^{123}$

There is also support for the first theory, that of pure nationalism. The second paragraph speaks of the "friends of our country," as if "our country" were an existing entity rather than merely a concatenation of separate units. 124 The fourth paragraph says that the "consolidation of our Union" is "the greatest interest of every true American," which again implies that a union already exists and that

\section{See app. at 649.}

120. See Akhil Reed Amar, The Consent of the Governed: Constitutional Amendment Outside Article V, 94 Colum. L. REv. 457, 507 (1994) ("[A] state people can be bound by a federal amendment even if that state people in [a] state convention explicitly reject[] the amendment."); see also Roger SHERMAN HOAR, CONSTITUTIONAL CONVENTIONS: THEIR NATURE, POWERS, AND LIMITATIONS 168-69 (1917) (arguing that the union of states in 1787 bound future state conventions to the Federal Constitution and eliminated their power to elect to do anything in contravention of the Constitution).

121. The Federalist No. 33 at 257 (Alexander Hamilton) (John C. Hamilton ed., 1865).

122. See also James Wilson, Pennsylvania Ratifying Convention (Dec. 4, 1787), reprinted in The Founders' Constitution at 62 (Philip B. Kurland \& Ralph Lemer eds., 1987) ("I consider the people of the United States as forming one great community, and I consider the people of the different States as forming communities again on a lesser scale.").

123. See app. at 649.

124. See id. 
Americans are in some sense already one people. ${ }^{125}$ Similarly, the fifth paragraph expresses the hope that the Constitution will "promote the lasting welfare of that country so dear to us all," rather than saying "those countries so dear to each of us."126 More to the point, the fourth paragraph warns that the consolidation of the Union involves "our prosperity, felicity, safety, perhaps our national existence."127 The clear implication is that, in some sense, there is already a national existence capable of being at risk, which is to say that the United States under the Articles of Confederation was already a nation of sorts rather than a league. ${ }^{128}$

On balance, the Washington letter seems clearly to endorse at least the transformational nationalism, if not the pure nationalism, theory of sovereignty. Thus, it provides important support for the views Justice Kennedy expressed when he broke ranks with the other New Federalists in the Term Limits case. He argued that the national government "owes its existence to the act of the whole people who created it" and stated that "the people of the United States . . . have a political identity as well, one independent of, though consistent with, their identity as citizens of the State of their residence."129 Moreover, the Washington letter is inconsistent with Justice Thomas's view that the people of the individual states retain their separate sovereignty as "the only true source of power."130

\section{B. Separate Spheres?}

The New Federalists stress aspects of the historical record that emphasize the limited powers of the federal government and the powers over local matters retained by the state governments. It is difficult to assess the import of some of these sources, although the federal government undoubtedly was not expected to be omnipotent. As Michael McConnell points out, this particular New Feder-

125. See id.

126. See app. at 650.

127. See app. at 649.

128. See Letter from George Washington to Charles Carter (Dec. 27, 1787), in 1 THE Debate ON THE CONSTITUTION 612 (Bemard Bailyn ed., 1993) (arguing for ratification of the Constitution: "I am fully persuaded [the Constitution] is the best that can be obtained at this Time ... and that it or Disunion is before us to choose from."); see also Abraham Lincoln Inaugural Address (Mar. 4, 1861), in KENNETH M. STAMPP, THE CAUSES OF THE CrvIL WAR 38-39 (1959). Abraham Lincoln stated that the Constitution is not a contract among states and that "[t]he Union is much older than the Constitution. It was formed, in fact, by the Articles of Association in 1774." Id. at 39.

129. United States Term Limits, Inc. v. Thornton, 115 S. Ct. 1842, 1872 (1995) (Kennedy, J., concurring).

130. 115 S. Ct. at 1876. 
alist argument may "confuse the founders' expectations about how the nation would be governed under the Constitution with the founders' understanding of the meaning of the Constitution."131

In any event, those taking a more expansive view of federal power also have identified support in the historical record for their position. One historian recently referred to the Convention as a "rally of nationalists."132 Another eminent historian observed that the Antifederalists "had no doubt that it was precisely an absorption of all the states under one unified government that the Constitution intended, and they therefore offered this prospect of an inevitable consolidation as the strongest and most scientifically based objection to the new system that they could muster."133 It is clear that the whole purpose of the Constitution was to strengthen the weak government the Articles of Confederation created; the question is how far down the road to centralized government the Framers intended to go. ${ }^{134}$

The Washington letter's discussion of governmental powers has a strongly nationalistic bent. It emphasizes the imperative of "consolidation of our Union" to further the interests of prosperity and security. It thereby embraced the very term - "consolidation" that represented the worst fears of the Antifederalists. It also portrays the goal of "fully and effectually vesting" key powers in the national government, in particular those relating to foreign affairs, taxation, and commerce. These powers are portrayed as too important to trust to any one body of men. Conspicuously, the letter

131. McConnell, supra note 34, at 1490 . For example, McConnell addresses whether the founders expected agriculture to become an important industry:

I agree ... that they did not. Hamilton, no advocate of "states' rights," wrote that "the supervision of agriculture and of other concerns of a similar nature ... which are proper to be provided for by local legislation, can never be desirable cares of a general jurisdiction." Does it follow that the Congress of 150 years later acted illegitimately when it concluded that regulation of agriculture was a "necessary and proper" means for curing national economic depression? The framers and ratifiers of the Constitution established rules and standards for determining the scope of national authority; that those rules and standards produce different outcomes in later circumstances is neither surprising nor troubling. ... [T] $]$ he founders' expectations about agriculture are interesting and important, but cannot take precedence over the constitutional standard.

Id. at 1490-91 (citations omitted).

132. See MORRIs, supra note 108 , at 269 . Because of his wartime experiences as commander of the Revolutionary Army, Washington took a particularly dim view of state prerogatives. See Glenn A. Phelps, George Washington and American Constitutionalism 127 (1993).

133. WooD, supra note 108 , at 526.

134. See Letter from Alexander Hamilton to James Duane (Sept. 3, 1780), in 1 THE FouNDERs' CONSTITUTION 150-53 (Philip B. Kurland \& Ralph Lemer eds., 1987) (summarizing complaints about Congress's lack of powers under the Articles). 
makes no mention of any specific areas being reserved out of federal jurisdiction.

It may be worth emphasizing that the Washington letter cited regulation of commerce as one of the key purposes of the Constitution, on par with national security. ${ }^{135}$ Thus, the New Federalists are wrong to say that the commerce power "was given no place of particular prominence" and was "only one among nearly a score of other powers."136

Apart from the Commerce Clause, the federal government was given an impressive array of economic powers. These powers were far-reaching in their own right and rather conspicuously extend to areas of allegedly "local" concern such as agriculture and manufacturing. A perusal of Article $I^{137}$ shows that the federal government had broad control over monetary policy and credit, via the bankruptcy power (as contrasted with the Contract Clause limitation on the states), the exclusive power to coin money, and the power to issue debt. The spending and taxing power gave the federal government the authority to encourage local industries through protective tariffs and to expend funds for vaguely defined purposes. ${ }^{138}$ The patent power also clearly intruded on the manufacturing sector, as did the power to establish a national system of standards. This array of powers makes it dubious to define local production as a distinctively state preserve from which the federal government was debarred.

It is understandable that the Antifederalists were alarmed by this transfer of powers to Congress. To see how important those powers were, suppose that a proposal were made to give the Organization of American States (OAS) the following powers: complete control of foreign affairs within and outside the hemisphere; the power to tax and spend money on the common welfare of the hemisphere; exclusive power to issue currency; control of commerce

135. See Alexander Hamilton's Conjectures About the New Constitution (Sept. 1787), in 1 THE DEBATE ON THE Constrtution, supra note 128, at 9 (listing circumstances that would weigh in favor of adoption of the new Constitution including "the good will of the commercial interest throughout the states which will give all its efforts to the establishment of a government capable of regulating protecting and extending the commerce of the Union").

136. EEOC v. Wyoming, 460 U.S. 226, 268 (1983) (Powell, J., dissenting). For the argument that commercial concerns were preeminent, see Jim Chen \& Daniel Gifford, Law As Industrial Policy: Economic Analysis of law in a New Key, 25 U. MEM. L. REv. 1315, 1322-25 (1995).

137. See U.S. CoNST. art. I.

138. Madison thought it was clear that the encouragement of manufacture was one of the purposes of the Commerce Clause. See Drew R. McCoy, THE Last of the Fathers: JaMES MAdison AND the REPUBLICAN LEGaCY 127 (1989). 
among the Americas and with other continents; jurisdiction over all cases involving the OAS charter and even over cases involving citizens of more than one country - and then add the proviso that the OAS's rule will be the "supreme law of the hemisphere."

In one sense, this is a limited set of powers. In another sense, these powers are broad enough that it would be quite understandable if today's equivalents of the Antifederalists thought that almost everything of importance had been lost. Quite likely, the full sweep of these powers would not be realized for decades, but no one would doubt that the potential for a tremendous reallocation of power was present. This is not to say that the OAS's powers would be unlimited or that the OAS courts would or would not be justified in attempting to draw some limits in construing those powers. But the charter would represent a shift in power away from more localized governments and a shift of the most profound kind.

As Madison said, and as the Lopez Court recounted, it is true that the powers of the federal government are "few and defined."139 But the Antifederalists were right to demur from the conclusion that, as a present-day commentator puts it, " $[t]$ his is not the stuff of which Leviathan is made."140 "Four score and seven years" after independence, after all, these powers proved quite sufficient to the task of crushing a rebellion by half the country, including some of the key original states, and in the process extirpating an institution fundamental to the economy and culture of those states. That action proved feasible, it bears noting, without whatever expansion of federal authority was to take place another seventy years later in the New Deal.

The Washington letter also contains another important clue about the scope of congressional power. Notice that the judicial power is described as "correspondent" with the great powers given Congress. ${ }^{141}$ Reversing the equation, an examination of the judicial power can help illuminate the scope of congressional power. During the founding period, the general presumption was that a government's legislative and judicial power must be coterminous. ${ }^{142}$ As Hamilton said in Federalist No. 80, "[i]f there are such things as political axioms, the propriety of the judicial power of a govern-

139. See United States v. Lopez, 115 S. Ct. 1624, 1626 (1995).

140. Lawson, supra note 94 , at 1234.

141. See app. at 649.

142. See G. Edward White, The Marshall Court and Cultural Change, 1815 1835, at 124-127, 486 (1988); G. Edward White, Recovering Coterminous Power Theory, 14 NovA L. REv. 155 (1989); see also Powell, supra note 115, at 660-61. 
ment being coextensive with its legislature may be ranked among the number."143

Hamilton was speaking in terms of federal question jurisdiction, but the remainder of Article $\mathrm{III}^{144}$ contains an important reminder for those who would narrowly define the sphere of federal authority and erect a protected bastion of exclusive state jurisdiction. Jurisdiction based on citizenship is a critical segment of Article III, and the result of diversity jurisdiction is that any dispute involving even one nonresident could be handed to the federal courts by Congress. ${ }^{145}$ At the time, it was far from clear that a federal court would have to follow state common law rulings - this was, after all, nearly a century and a half before the Erie doctrine was announced. ${ }^{146}$ Note that the state courts were to be displaced in a broad range of cases, not just commercial ones, and certainly not just cases involving the interstate trade in goods. In addition, the federal courts were given jurisdiction through the Admiralty Clause of the major mode of transportation, whether or not any particular litigation involved either citizens of different states or interstate commerce. Once again, the idea of protecting traditional areas of state concern from federal intrusion seems not to have been at the forefront. The focus was on the need to enhance federal power, not on the need to protect state jurisdiction, whether legislative or judicial.

An understanding of the coterminous power axiom would have prevented a misstep by the New Federalists in New York $v$. United States. ${ }^{147}$ In New York, Justice O'Connor's opinion for the Court insisted that Congress lacks the power to issue affirmative mandates to state governments. ${ }^{148}$ It is quite clear, however, that federal courts do have the power to issue affirmative mandates to the states. ${ }^{149}$ The Washington letter's description of the judicial power

143. The Federalist No. 80 (Alexander Hamilton).

144. See U.S. CONST. art. III.

145. See U.S. CoNST. art. III. Consistently with the coterminous power thesis, Justice Marshall spoke of Congress as lacking legislative power in just those cases in which the federal courts would lack diversity jurisdiction, when he denied that Congress could make "laws affecting the mode of transferring property, or contracts, or claims, between citizens of the same state." See United States v. Lopez, 115 S. Ct. 1624, 1645-46 n.4 (1995) (quoting Marshall).

146. See Erie Railroad v. Tompkins, 304 U.S. 64 (1938). Note that judicial power retained its broad scope until just the time when legislative power had expanded enough to take its place.

147. 505 U.S. 144 (1992).

148. See 505 U.S. at 166.

149. See, e.g., Swann v. Charlotte-Mecklenburg Bd. of Educ., 402 U.S. 1 (1971); Colorado v. New Mexico, 459 U.S. 176, 185 (1982); Wyoming v. Colorado, 259 U.S. 419, 484 (1922). 
as "correspondent" with congressional power suggests strongly that the courts have no greater power to invade the prerogatives of the states - or conversely put, that Congress has as much power to do so as the federal courts. 150 Given the unchallenged rule that the federal courts do indeed have such power, congressional power to issue affirmative mandates to the states necessarily follows, via the coterminous power axiom.

\section{Federalism as a Fundamental Value}

What of the role of the states as independent guardians of liberty? Was this an important animating motive behind the drafting of the Constitution? Not if the Washington letter is any indication. It does speak at length about the need to respect the interests of various states so as to convince them to agree to a stronger Union. But the letter does not say a word about the importance of maintaining the states as a check on the federal government. ${ }^{151}$ The only reference to the need to restrain the possible abuse of federal power is in the second paragraph. There the letter states that the commerce, tax, and war powers are too dangerous to entrust to any one body, so a "different organization" was needed. ${ }^{152}$ The solution was to divide those powers among more than one body - the House, the Senate, and the President - so as to prevent abuse. Thus, the letter does refer obliquely to the separation of powers as a safeguard against the abuse of federal power, but nowhere does it refer, even obliquely, to federalism as such a safeguard.

This omission should not be surprising, for the evidence cited by the New Federalists on this point stems exclusively from the ratification period, rather than the Convention or an earlier period. Justice O'Connor's opinion in Gregory v. Ashcroft, for example, relies solely on two paragraphs from the Federalist Papers for historical support. ${ }^{153}$ Perhaps even more strikingly, Michael McConnell's historical analysis relies quite heavily on the views of the Antifederal-

150. See app. at 649.

151. Indeed, a justification for granting the federal government greater powers was that, due to self-interest, it was more likely that abuses of power would occur if the state govemments held a power than if the federal government held it. See ThE FEDERALIST No. 59, at 452-53 (Alexander Hamilton) (John C. Hamilton ed., 1864) ("The people of America may be warmly attached to the government of the union, at times when the particular rulers of particular states .... are capable of preferring their own emolument and advancement to the public weal.").

152. See app. at 649.

153. See 501 U.S. $452,457-58$ (1991). 
ists and stresses their desire to maintain state autonomy. ${ }^{154}$ Indeed, as Jefferson Powell has documented, the views of the leading New Federalists, such as Chief Justice Rehnquist and Justice O'Connor, have as much in common with those of the Antifederalists as with those generally expressed by the Constitution's supporters. ${ }^{155}$ In essence, the New Federalists seem to view the Constitution almost as if it was a compromise between those who drafted it and their opponents.

Justice Powell's dissent in Garcia ${ }^{156}$ offers an argument for the existence of this post-Convention compromise. According to Justice Powell,

Much of the initial opposition to the Constitution was rooted in the fear that the National Government would be too powerful and eventually would eliminate the States as viable political entities. This concern was voiced repeatedly until proponents of the Constitution made assurances that a Bill of Rights, including a provision explicitly reserving powers in the States, would be among the first business of the new Congress. ${ }^{157}$

Powell goes on to cite Samuel Adams and George Mason, both prominent opponents of the Constitution, on the dangers of national power. He then adds that "Antifederalists raised these concerns in almost every state ratifying convention."158 Then, the story continues:

So strong was the concern that the proposed Constitution was seriously defective without a specific bill of rights, including a provision reserving powers to the States, that in order to secure the votes for ratification, the Federalists eventually conceded that such provisions were necessary. It was thus generally agreed that consideration of a bill of rights would be among the first business of the new Congress. Accordingly, the 10 Amendments that we know as the Bill of Rights were proposed and adopted early in the first session of the First Congress. ${ }^{159}$

154. See McConnell, supra note 34, at 1493 (relying on the "Federal Farmer"); see id. at 1500 (quoting Patrick Henry); see id. at 1507-08 (quoting from an Antifederalist essay, Brutus); see id. at 1509 (relying again on the Federal Farmer).

155. See Jeff Powell, The Compleat Jeffersonian: Justice Rehnquist and Federalism, 91 YALE L.J. 1317 (1982); Powell, supra note 115 (discussing Justice O'Connor). Thus, from a historian's perspective, members of the school of thought discussed in this essay equally well might be called the New Antifederalists.

156. Garcia v. San Antonio Metro. Transit Auth., 469 U.S. 528, 557 (1985) (Powell, J., dissenting).

157. 469 U.S. at 568.

158. 469 U.S. at 569 (citation omitted).

159. 469 U.S. at 569 (citations omitted). A similar theory is found in BERGER, supra note 28 , at $78-80$. 
This is certainly not an unconventional view of the origins of the Bill of Rights, but it suffers from two weaknesses. The first objection is formalist. To paraphrase Judge Easterbrook, what matters is not the intention of the Framers of the Tenth Amendment to protect the states but the language they enacted. That language is only a truism that adds nothing of substance to the Constitution. ${ }^{160}$ The second objection is historical. The adoption of the Bill of Rights actually was not compelled as a part of a deal integral to the inauguration of the new government. In fact, after ratification, interest quickly waned in adopting a Bill of Rights, and Madison had great difficulty in even getting the matter on the House floor. ${ }^{161}$ Notably, both former Federalists and Antifederalists opposed consideration of a Bill of Rights in the first Congress. Antifederalist interest in a Bill of Rights seems, in many cases, to have been primarily a ploy to derail ratification. ${ }^{162}$

On balance, whatever verbal assurances that the Federalists felt called upon to offer on occasion during the ratification debates, these assurances provide little ground to infer a change in the general understanding of the meaning of the document between the time it was proposed and the time it was ratified. No doubt the Constitution was adopted against a background of deep attachment to the states, but the document gives little sign of constitutionalizing states' rights as a fundamental value. Nor did the Tenth Amendment work any substantive change in federal power. As formalists like Justice Scalia and Judge Easterbrook have reminded us, it is important not to confuse the general views and desires of those who create laws with the content of what they have actually enacted. ${ }^{163}$

\section{CONCLUSION}

This essay has been concerned with the core of "original intent": the general understanding of the meaning of the text at the time of enactment. I find it somewhat unrealistic to posit a single original understanding. For example, Madison took a notoriously short time to discover that his understanding of the text was rather differ-

160. The Tenth Amendment is probably best understood as a counter to the Antifederalist argument that because the new govemment would be sovereign and because sovereignty is inherently unlimited, all of the powers of government were necessarily possessed by the federal government.

161. See FARBER \& SHERRY, supra note 86, at 226. Even after he introduced the Bill of Rights, Madison had difficulty persuading his colleagues to view the matter as important. See id. at 231-32.

162. See id. at 227.

163. See supra text accompanying notes 79-82, 86 \& 97-99. 
ent from that of his fellow delegates Hamilton and Washington. ${ }^{164}$ It might be more accurate, therefore, to speak of the range of original understandings that the text was capable of supporting in its historical context. Most constitutional scholars would disagree with the assertion that original intent, defined in these terms, is the beginning and end of constitutional interpretation, but few would reject its relevance.

Extracting some understanding of the original intent from a large and confusing historical record is a tricky job even for professional historians specializing in the period. This task is all the more difficult for judges and constitutional lawyers. One purpose of this essay is to suggest a more self-conscious selection of sources that is keyed to our normative theory of constitutional interpretation. If our normative theory requires us to determine the general understanding of the text, we are particularly in need of reliable evidence of widely shared understandings, as opposed to the viewpoints of a few individuals at a particular time. We also need to distinguish between meanings that are directly attributable to the text and ideas reflecting background assumptions and values that may or may not have been incorporated in the text and to do so carefully. Unfortunately, reliability is also a problem in terms of ascertaining the content of the key debates of the framing period.

The essay puts forward, as a candidate for particular attention in reconstructing the original understanding, the cover letter from the Constitutional Convention, which was signed by George Washington on behalf of the Convention and accompanied the transmittal of the Constitution to the Continental Congress and to the states.

Using the Washington letter for guidance, we can gauge the extent to which the text of the Constitution was intended to reinforce the national government as opposed to embracing the states. This question is obviously a matter of degree. The Framers clearly did not envision an omnipotent federal government, on the one hand, but they did mean to strengthen it greatly. The New Federalists have argued that the states were meant to retain sovereign regulatory authority and that the preservation of this authority was central to the constitutional design for protecting liberty. The Washington letter does contemplate the continued independent existence of the states and suggests that their interests will be

164. For a recent discussion of the Framers' traumatic discovery that they were deeply divided about how to implement the powers of the new government, see JAMES ROGER Sharp, American Polmics in the Early Republic: The New Nation In Crisis (1993). 
served best by adoption of the Constitution. But it treats the states more as a fact of life than as essential safeguards of liberty and rejects the idea that they will retain their independent sovereignty after ratification. Thus, to the extent that the philosophy embraced by the New Federalists such as Justices O'Connor and Thomas claims to flow from the original understanding of the Framers, it has a shaky foundation. ${ }^{165}$

165. Of course, the results in particular cases such as Lopez may be valid, even if the theory invoked to support them has a weak foundation. For most of us, the correctness of these decisions cannot be decided solely on the basis of original intent. In considering the ultimate constitutional questions presented by these cases, it is well to remember the teaching of Justice Holmes that the Framers "called into life a being the development of which could not have been foreseen completely by the most gifted of its begetters." "It was enough for them," Holmes went on to say, "to realize or to hope that they had created an organism; it has taken a century and has cost their successors much sweat and blood to prove that they created a nation." So, he concluded, questions of national power must be considered in the light of our whole history, not merely on the basis of original intent. Missouri v. Holland, 252 U.S. 416, 433 (1920); see also Lawrence Lessig, Understanding Changed Readings: Fidelity and Theory, 47 STAN. L. REV. 395, 443-72 (1995) (discussing constitutional evolution and the New Deal). For further reflections on the role of original intent in constitutional interpretation, see FARBER \& SHERRY, supra note 86, at 392-94. For an interesting discussion of Madison's views on the need to respect established readings of the Constitution, see McCoY, supra note 138, at 128. Whether Lopez and other New Federalist opinions pass muster under this standard is a question for another day. 


\section{APPENDIX}

Letter of the President of the Federal Convention, Dated September 17, 1787, to the President of Congress, Transmitting the Constitution.

In Convention, September 17, 1787.

Sir,

We have now the honor to submit to the consideration of the United States in Congress assembled, that Constitution which has appeared to us the most adviseable.

The friends of our country have long seen and desired, that the power of making war, peace, and treaties, that of levying money and regulating commerce, and the correspondent executive and judicial authorities should be fully and effectually vested in the general government of the Union: But the impropriety of delegating such extensive trust to one body of men is evident - Hence results the necessity of a different organization.

It is obviously impracticable in the federal government of these states, to secure all rights of independent sovereignty to each, and yet provide for the interest and safety of all: Individuals entering into society, must give up a share of liberty to preserve the rest. The magnitude of the sacrifice must depend as well on situation and circumstance, as on the object to be obtained. It is at all times difficult to draw with precision the line between those rights which must be surrendered, and those which may be reserved; and on the present occasion this difficulty was increased by a difference among the several states as to their situation, extent, habits, and particular interests.

In all our deliberations on this subject we kept steadily in our view, that which appears to us the greatest interest of every true American, the consolidation of our Union, in which is involved our prosperity, felicity, safety, perhaps our national existence. This important consideration, seriously and deeply impressed on our minds, led each state in the Convention to be less rigid on points of inferior magnitude, than might have been otherwise expected; and thus the Constitution, which we now present, is the result of a spirit of amity, and of that mutual deference and concession which the peculiarity of our political situation rendered indispensible.

That it will meet the full and entire approbation of every state is not perhaps to be expected; but each will doubtless consider, that had her interest been alone consulted, the consequences might have been particularly disagreeable or injurious to others; that it is liable 
to as few exceptions as could reasonably have been expected, we hope and believe; that it may promote the lasting welfare of that country so dear to us all, and secure her freedom and happiness, is our most ardent wish.

With great respect, We have the honor to be, Sir, Your Excellency's

most obedient and humble servants,

George Washington, President

By unanimous Order of the Convention.

His Excellency the President of Congress. 